\title{
PSYCHOLOGICAL EFFECT OF CUSTOMERS TO THE RE-PURCHASE DECISION OF AIRBNB ACCOMMODATION FACILITIES IN JAKARTA
}

Asep Parantika 1 , RR. Cindy Diana Nadia Lolita. E.P ${ }^{2}$

${ }^{1,2}$ Politeknik Sahid, Jakarta, Indonesia, email: asepparantika@polteksahid.ac.id

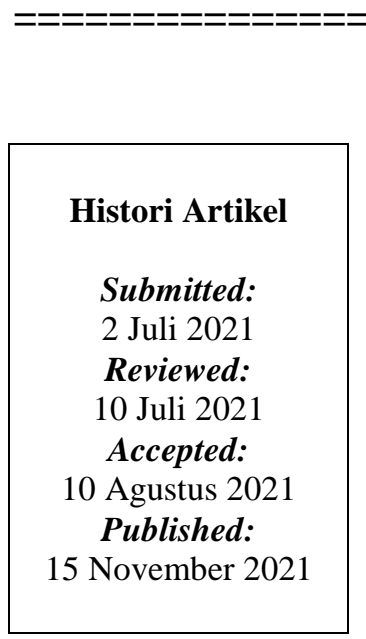

\begin{abstract}
Attitude repurchase decision influenced by other three components, which are stay experience. This article aims to discover the psychological effect of customers' service to the re-purchase decision of AirBNB accommodation facilities in Jakarta. The research use quantitative analysis. Data collection technique used are questionnaire circulation and literature reviews. The result shows that there are three components influencing respondents to reuse AirBNB services, which are Motivation, Perception, and, Users Review, and Price Sensitivity. Every component provides each influence in determining the repurchase decision of AirBNB. Service psychology hold a great impact on the AirBNB repurchase decision. Other components such as
\end{abstract} motivation, perception, and attitude play significant roles in the decision and greatly impacted the customers, as well as other factors such as stay experience, guest review and price sensitivity.

Keywords: Air BNB, Service Psychology, Repurchase Decision

\section{PENGARUH PSIKOLOGIS PELANGGAN TERHADAP KEPUTUSAN PEMBELIAN KEMBALI FASILITAS AKOMODASI AIRBNB DI JAKARTA}

\section{ABSTRAK}

Keputusan pembelian ulang dipengaruhi oleh tiga komponen lainnya yaitu pengalaman menginap. Artikel ini bertujuan untuk mengetahui pengaruh psikologis pelayanan pelanggan terhadap keputusan pembelian ulang fasilitas akomodasi AirBNB di Jakarta. Penelitian menggunakan analisis kuantitatif. Teknik pengumpulan data yang digunakan adalah sirkulasi angket dan studi pustaka. Hasil menunjukkan bahwa ada tiga komponen yang mempengaruhi responden untuk menggunakan kembali layanan AirBNB, yaitu Motivasi, Persepsi, dan, Review Pengguna, dan Sensitivitas Harga. Setiap komponen memberikan pengaruh masingmasing dalam menentukan keputusan pembelian kembali AirBNB. Psikologi layanan berpengaruh besar terhadap keputusan pembelian ulang AirBNB. Komponen lain seperti motivasi, persepsi, dan sikap memainkan peran penting dalam keputusan dan sangat memengaruhi pelanggan, serta faktor lain seperti pengalaman menginap, ulasan tamu, dan sensitivitas harga.

Kata Kunci: Air BNB, Pisikologi pelayanan, Keputusan Pembelian

\section{INTRODUCTION}

Tourism is a journey and travelling activities, conducted either individually or in group, with the sole purpose of leisure or vacation in a tourism area with accommodation service to meet the necessities of these travelers. Tight competitions in this service industry resulted in a race of providing the best services for their customers or guests. One of the approaches of improving services is observed from the angle of service providers' psychology where they could 
study the customer behavior while having day by day interaction with them.

Accommodation growth in hospitality or tourism industry unquestionably not only generates competition but also brings various products and new accommodation service standard emerged from the cutting-edge technology and internet.

Nowadays internet provides online shopping business, which is very profitable due to greater market share and ease the customers in selecting and acquiring their shopping option. In addition, accommodation industry has benefited by this technology as well.

Indonesia's service and accommodation industry has experience a significant improvement by the hike of room reservations through mobile phone application or internet. Online Travel Agent (OTA) has turned into the most common way by customers to book a room. There are many OTA applications system in Indonesia since it is proven to be an effective marketing tool. Technology innovation has simplified the process of new comer entry toward the sharing economy.

Airbed \& Breakfast (Airbnb) is an online application system with various facilities and lower rate than other conventional accommodation providers. Airbnb provides service as a third party in accommodation segment by connecting accommodation provider/owner with customer/guest, and particularly fulfill the requirements of accommodation in lower rate and at ease ventures than local community. On the other hand, market share become narrow and without doubt this service sector has evoked wider competitiveness among them in acquiring online reservations. As a result, and due to the competition and the uncertainty of accommodation qualities of Airbnb, customers tend to peruse specific detail information concerning products or services to purchase through online applications, particularly accommodation services.
Electronic Word of Mouth (E-WOM) is essential for online accommodation providers because online reviews take part as the medium for customers to find out appropriate required information regarding the online accommodation service. In the online reviews, customers could seek out all reviews and references about stay experience and rate/price sensitivity of the service provider. These two could impact positively or negatively to the reputation of online accommodation services. Customers could be stirred by the reviews shared, and it shall influence the buying decision. Hence, writer would like to emphasis this research in finding out the effect of customer's service psychology to the decision of re-purchase of Airbnb facilities.

\section{LITERATURE REVIEW}

It is Sharing Economy Time

Cohen dan kitzeman (qtd. In Sijabat, 2019:67) "The sharing economy is a form of economic transaction that takes place in real time using the internet and other technologyrelated devices to facilitate people to find individuals who meet their needs without transaction activities like a traditional market". Share Economy is a new innovation which allowed a person to own product, food, money, transportation or service to demanding customer with lower rate.

The Importance of Service Psychology

Sarwono (qtd. In Effendi, 2016:2) quoted that psychology is a science that study human behavior who want to recognize the compulsion behind individual behavior, to predict future behavior, and to oversee the behavior to prevent and to manage any unsuccessful condition".

Conducted by company for customer with interest to obtain the product (Tjiptono qtd. In Setiawan dan Juliansyah, 2017: 108). A service is developed due to the process of servicing from service provider to the served party (Brata identify qtd. In Setiawan dan Juliansyah, 2017: 108) 
The customer's repurchase decision

Customer shall re-purchase the same product even if without emotional interest whatsoever. (Hawkins and Mothersbaugh, qtd. In Soediono, 2016:110). Overtime, most customers will become repeaters. This is largely influenced by satisfaction level of the customers, and for those who haven't accustomed to the product, will be very much provoked by word of mouth or by reviews from previous customers. Nowadays in the era of internet, online review is very influential. Thurau et al. (qtd. In Sari and Pangestuti, 2018:191) revealed that E-WoM is a certain form of marketing communication contain positive or negative statement, regarding a specific product that available for many people, thru potential and or prior customers over social media and internet.

\section{METHODOLOGY}

This research used a quantitative correlative research method by collecting information, circulating questioners and defining connection between independent variable (X) and related variable (Y). Primary data collection use survey method and questioner instrument given the Likert scale to customers of Airbnb accommodation in Jakarta.

To simplify data calculation obtained by using statistical analysis via SPSS with the purpose of to know examined variables, whereas Re-purchase Decision (Y) as related variable and Customer Service Psychology (X) as independent variable. Populace in this research are consumers live in DKI Jakarta area, by 4,431,567 individuals in average age up to 36 years old (katadata.com,2020). With 100 samples taken from total sample calculation using Slovin formula with error margin of $5 \%$ to $10 \%$. Due to Covid-19 pandemic, unfortunately on site research is unmanageable hence this research is conducted online.

\section{RESULTS AND DISCUSSION}

Airbnb is the abbreviation of air bed and breakfast, established in 2008 located in San Francisco, California. The form of business is connecting two parties, one who seek accommodation and one is the accommodation provider with properties to lease, either a house, apartment, or private room.

Airbnb covers large areas across the globe, with currently over 200 million travelers have stayed in more than 1 million locations in 65 thousand cities and 191 countries. Airbnb offers various range of its partners' accommodations, appealing customers from online to on-site. The user friendly look surely make online visitors easy to find whatever accommodation they need.

\section{Respondent Characteristic}

\section{Respondent Profile Based On Gender}

This research required 2 types of respondents, man and woman. Out of 100 respondents, 37 are men with $37 \%$ of total samples, and the rest are $63 \%$ women. Proven that more users of Airbnb application are women compare to men.

\section{Respondent Profile Based On Age}

Respondent in age basis are divided into 5 categories of age. Out of 100 respondents, 13 respondents are $<19$ years old or $13 \% .50 \%$ respondents are in 20-24 years of age, $23 \%$ respondents are in 25-29 years of age, $10 \%$ respondents are in 30-34 years of age, and $4 \%$ in the age of $>35$ years old. From the data, could be concluded that average age of Airbnb application users are in their 20-24 years of age, as that age is a productive age with plenty of time for travelling.

\section{Respondent Profile Based On Occupation}

Out of 100 samples, $55 \%$ respondents are students/college students, $13 \%$ respondents are entrepreneur, $20 \%$ respondents are employees from private sector, 5\% respondents are civil servant/army/police and $7 \%$ of other occupations. From the data, could be concluded that average age of 
Airbnb application users are students/college students. They have plenty of time to travel and to visit tourism sites.

\section{Likert Scale}

Variabel X (Customer Service Psychology)

Next id the description of $X$ variable indicator (Customer Service Psychology)

$\mathrm{X}$ 55\% respondent agree, to choose Airbnb accommodations due to the quality assurance

$\mathrm{X} 52 \%$ respondent agree with the affordable rate of Airbnb accommodations

X $44 \%$ respondents agree with the accessible location

$\mathrm{X} 46 \%$ respondents agree with the unique characteristic and ambiance of Airbnb properties .
X $40 \%$ respondents feel that Airbnb provides clear information regarding the properties

$\mathrm{X} 56 \%$ respondents feel that service and facilities of Airbnb are quite satisfactory

X $53 \%$ respondent feel that Airbnb accommodation are diverse and modern

X 64\% respondents will recommend Airbnb accommodations to others

X $51 \%$ respondent agree that Airbnb accommodations and properties suitable to their expectation

\section{Recap Table of Variable X Respondents Reply}

\begin{tabular}{|c|c|c|c|c|}
\hline No & Statement & Result & Score & Remarks \\
\hline 1 & $\begin{array}{l}\text { I choose Airbnb accommodations due to the quality } \\
\text { assurance }\end{array}$ & 433 & 4.33 & Remarkable \\
\hline 2 & I think Airbnb accommodation rate is affordable & 424 & 4.24 & Remarkable \\
\hline 3 & $\begin{array}{l}\text { I use Airbnb accommodation because the location is } \\
\text { accessible }\end{array}$ & 411 & 4.11 & Good \\
\hline 4 & $\begin{array}{l}\text { I think Airbnb properties have unique ambiance and } \\
\text { characteristic }\end{array}$ & 381 & 3.81 & Good \\
\hline 5 & Airbnb provides clear information about the accommodations & 380 & 3.80 & Good \\
\hline 6 & $\begin{array}{l}\text { Airbnb accommodations provides satisfactory service and } \\
\text { facilities }\end{array}$ & 422 & 4.22 & Remarkable \\
\hline 7 & Airbnb accommodation are diverse and modern & 409 & 4.09 & Good \\
\hline 8 & I will recommend Airbnb accommodations to others & 399 & 3.99 & Good \\
\hline 9 & $\begin{array}{l}\text { Airbnb accommodations and properties suitable to the } \\
\text { expectation }\end{array}$ & 387 & 3.87 & Good \\
\hline Avers & & & 4.05 & \\
\hline
\end{tabular}

Numbers on the recapitulation table of Variable $\mathrm{X}$ respondents are taken from total scores of each statement given by respondents. It could be concluded that consumers service psychology is good, with overall average of 4.05 in the research interval of $4.19-3.40$.

\section{Variable Y (Re-purchase Decision)}

Next is the description of $\mathrm{Y}$ variables indicator (Re-purchase Decision)

Y $33 \%$ respondent agree that Airbnb properties provide homey ambiance
Y 33\% respondent agree that during their stay in Airbnb accommodations, they could build good rapport with the locals.

Y 63\% respondent agree that by staying in Airbnb properties they experience good exposure with the locals and grow good understanding of the traditions of the locals.

Y 59\% respondents like to read other travelers' online reviews to find out whether Airbnb bring good impression to other customers 
Y 45\% respondents said that to ensure they pick great choice of Airbnb accommodation, respondents often read other travelers' online review

Y $45 \%$. Respondents develop communication with other travelers to assist them select good accommodation of Airbnb

Y 58\% respondent state that rate or cost of the accommodation is crucial to customers

Y 48\% respondent state that they don't mind paying more to stay in Airbnb accommodation

Y 50\% respondents are willing to spend more on Airbnb accommodation if it is cheaper than hotel room

\section{Recapitulation table of $Y$ Variable respondent response}

\begin{tabular}{|c|c|c|c|c|}
\hline No & Statement & Result & Score & Remarks \\
\hline 1 & $\begin{array}{l}\text { Airbnb properties provide homey ambiance } \\
\text { During stay in Airbnb accommodations, we could build } \\
\text { good rapport with the locals. }\end{array}$ & 360 & 3.60 & Good \\
\hline 2 & & 378 & 3.78 & Good \\
\hline 3 & $\begin{array}{l}\text { Staying in Airbnb properties we experience good exposure } \\
\text { with the locals and grow good understanding of the } \\
\text { traditions of the locals }\end{array}$ & 428 & 4.28 & Remarkable \\
\hline 4 & $\begin{array}{l}\text { I like to read other travelers' online reviews to find out } \\
\text { whether Airbnb bring good impression to other customers } \\
\text { To ensure I pick great choice of Airbnb accommodation, I } \\
\text { often read other travelers' online review }\end{array}$ & 428 & 4.28 & Remarkable \\
\hline 5 & & 310 & 3.10 & Satisfactory \\
\hline 6 & $\begin{array}{l}\text { I develop communication with other travelers to assist } \\
\text { them select good accommodation of Airbnb }\end{array}$ & 420 & 4.20 & Remarkable \\
\hline 7 & Rate or cost of the accommodation is crucial to customers & 436 & 4.36 & Remarkable \\
\hline 8 & $\begin{array}{l}\text { I don't mind paying more to stay in Airbnb } \\
\text { accommodation }\end{array}$ & 418 & 4.18 & Good \\
\hline \multirow[t]{2}{*}{9} & $\begin{array}{l}\text { I am willing to spend more on Airbnb accommodation if it } \\
\text { is cheaper than hotel room }\end{array}$ & 424 & 4.24 & Remarkable \\
\hline & Average & & 4.00 & \\
\hline
\end{tabular}

Numbers on the recapitulation table of Variable $\mathrm{Y}$ respondents are taken from total scores of each statement given by respondents. It could be concluded that consumers' repurchase decision is good, with overall average of 4.00 in the research interval of $4.19-3.40$.

\section{Validity Test}

Validity test is specific test to determine the validity of data obtained through questioner. A questioner is valid when it could reveal the thing to be measured in the questioner. Validity test is conducted by calculating total 
score that is going to be measured using Coefficient Correlation Process in SPSS. The result shows that all data in Variable $\mathrm{X}$ and variable $Y$ are valid since $R$ value of $X$ variable and $\mathrm{Y}$ is higher than $\mathrm{R}$ table used.

\section{Reliability Test}

This test is the tool used to acknowledge the reliability of questioner. Questioner is reliable with score of 0.830 . Based on the value of > Cronbach's Alpha $(0,6)$, the questioner is reliable and can be used in data collection measurement.

\section{Classic Assumption Test}

Normality Test with Normality test Kolmogorov-Smirnov Test

Show that data is normally distributed with sig. score 0.139 higher than 0,05 .

\section{Heteroscedasticity Test}

The result is not heteroscedasticity because there are no marks formed specific pattern and marks distribution are under and above zero on $\mathrm{Y}$ axis

\section{Correlation of Moment Product}

Coefficient correlation shows a correlation between variables in this research. Researcher uses Pearson Coefficient correlation with SPSS software to test the connection. Result shows that correlation value calculate with Pearson's correlation is 0.578 which is in the interval of 0,40 0,5999 in table 3.3. This means that there is a mild and positive correlation between customer service psychology and customer re-purchase decision.

It can be concluded that when the customer service psychology goes well, hence it could generate the repurchase decision of customer, and vice versa when the customer service psychology does not run well, hence it could decline the repurchase decision of customer. Customer service psychology is correlate and has an impact to the repurchase decision of Airbnb accommodation.

\section{Determinant Coefficient}

Based on the calculation of coefficient correlation test, it is concluded that the percentage of customer service psychology influence to the customer repurchase decision of Airbnb accommodation is $32,4 \%$ and the rest of $67,6 \%$ determined by rate, culture, economic environment, life style, and others.

\section{CONCLUSION}

Based on the research it could be concluded that customer service psychology influences the repurchase decision of Airbnb accommodation with product moment correlation of 0,578 . It could be said that when customer service psychology works well then it could affect the decision of repurchase the Airbnb accommodation.

Based on the research, can be concluded that: customer service psychology influence to the customer repurchase decision of Airbnb accommodation is $32,4 \%$ and the rest of $67,6 \%$ determined by rate, culture, economic environment, life style, and others.

Based on the research, writer would like to suggest that Service Accommodation Providers/ Owners could provide thorough detail information regarding the accommodation facilities to be rent so that users or customers could find the perfect accommodation suitable to their needs. Accommodation providers are expected to escalate and improve the good service for customers so as to customers could give positive review or feedback about their stay experience.

\section{REFERENCES}

Caraka, G. P. (2015). Peranan Karakteristik dan Psikologi Konsumen terhadap Keputusan Pembelian Kembali Produk Pakaian melalui Instagram. $e$ Proceeding of Management, 130. 
Dao, N. L., \& Vu, A. (2016).

Customers'Purchasing Behavior

Between Airbnb And Hostels When

Travelling To Helsinki. Haaga-Helia

University of Applied Sciences, 9.

Fredereca, B. G., \& Chairy. (2010).

Pengaruh Psikologi Konsumen Terhadap

Keputusan Pembelian Kembalai

Smartphone Blackberry. Jurnal

Manajemen dan Terapan, 133.

Halin, H., Wijaya, H., \& Yusilpi, R. (2017).

Pengaruh Jual Kaca Patri Jenis Silver

Terhadap Nilai Penjualan Pada CV.

Karunia Kaca Palembang. Jurnal

Ecoment Global, 53.

Hermawan , I. (2019). Metodologi Penlitian

Pendidikan Kuantitatif, Kualitatif dan

Mixed Methode . Kuningan: Hidayatul

Quran Kuningan.

Liang, L. J., Choi, H. C., \& Joppe, M. (2018). Understanding Repurchase Intentions Of Airbnb Consumers: Perceived Authenticity, EWoM, And Price Sensitivity. Journal of Travel \& Tourism Marketing, 23.

Nugroho, E. (2018). Prinsip-Prinsip Menyusun Kuesioner. Malang: UB Press.

Oping, N., Lapian, J., \& Soegoto Supandi, A. (2015). Pengaruh Faktor Psikologis Konsumen Terhadap Impulsif Buying Pada Produk Konsumsi Rumah Tangga Di Sakura Mart Amurang. Journal Riset Ekonomi, Manajemen, Bisnis dan Akuntan , 107.

P, I. I., \& Cahyaningrum, I. (2019). Cara Mudah Memahami Metodologi

Penelitian . Yogyakarta: Deepublish .

Purnamasari, D., \& Yulianto, E. (2018). Analisis Electronic Word Of Mouth Terhadap Keputusan Pembelian Produk Smartphone Oppo Dengan Brand Image
Dan Brand Trust Sebagai Variabel

Moderator. Jurnal Administrasi Bisnis, 94.

Ridha, N. (2017). Proses Penelitian,

Masalah, Variabel Dan Paradigma

Penelitian. Jurnal Hikmah, 66.

Sari, F., \& Pangestuti, E. (2018). Pengaruh

Electronic Word Of Mouth ( E-wom)

Terhadap Minat Berkunjung dan

Keputusan Berkunjung . Jurnal

Administrasi dan Bisnis, 191.

SB, H. (2013). Model Howard \& Sheth Sebagai Alternatif Memahami Perilaku

Konsumen Dalam Manajemen

Pemasaran. Dharma Ekonomi-STIE

Dharmaputra, 3.

Setiawan, B., \& Juliansyah, R. (2017).

Faktor-Faktor Yang Mempengaruhi

Kepuasan Pengunjung Terhadap

Pelayanan Barista Coffe Shop Aronani

Hotel Hail, Saudi Arabia. Journal Sains

Terapan Pariwisata, 108.

Sijabat, R. (2019). Sharing Economy : A

Study On The Factors Influencing Users

Motivation To Use Ride Sharing

Platforms. DeReMa Jurnal Manajemen, 67.

Sugiarto, Hendratono, T., \& Sudibyo, D.

(2015). Metodologi Penelitian

Hospitaliti dan Pariwisata. Tangerang:

PT. Matana Publishing Utama.

Sugiyono. (2018). Metode Penelitian

Kuantitatif, Kualitatif dan $R \& D$.

Bandung: Alfabeta.

Tersiana, A. (2018). Metodologi Penelitian. Yogyakarta: Yogyakarta.

Usman, E. (2016). Psikologi Konsumen. Jakarta: Rajawali. 
Wahono, F. A., \& Kartika, E. W. (2017). Consumer Behavior Study. Jurnal Hospitality dan Manajemen Jasa, 546.

Waluya, B. (2007). Sosiologi : Menyelami Fenomena Sosial di Masyarakat. Bandung: PT Setia Purna Inves.

Wulandari, D. R. (2014). Pengaruh Psikologi Konsumen Terhadap Keputusan
Menggunakan Layanan Jasa Perbankan. Jurnal Manajemen dan Bisnis , 2.

Zahra, R. R., \& Rina, N. (2018). Pengaruh Celebrity Endorser Hamidah Rachmayanti Terhadap Keputusan Pembelian Produk Online Shop Mayoutfit Di Kota Bandung. Jurnal Lontar, 49-50 